\title{
Teachers Professional Induction in the Czech Republic and Slovakia
}

\author{
Miluse Viteckova1, Zdenka Gadusova ${ }^{2, *}$ \\ ${ }^{1}$ Department of Pedagogy and Psychology, Faculty of Education, University of South Bohemia in ČeskéBudějovice, Czech Republic \\ ${ }^{2}$ Department of English and American Studies, Faculty of Arts, Constantine the Philosopher University in Nitra, Slovakia \\ *Corresponding author: zgadusova@ukf.sk
}

Received October 04, 2014; Revised November 18, 2014; Accepted December 01, 2014

\begin{abstract}
The paper presents partial results of research carried out among novice teachers and mentors with a special focus on teachers' professional induction in the Czech Republic and Slovakia. The aim of this research was to identify problematic areas novice teachers face, opportunities for novice support in the form of appointed mentors and, furthermore, the research has relevance also because of its impact on the higher education training of future teachers. Another aim of this Czech and Slovak research was to find out the differences in the area of CPD of teachers between these two countries which used to form one common country before the year 1993 and, consequently, had a common history. In both countries mixed research has been carried out, using questionnaires and semi-structured interviews. In the Czech Republic 148 novice teachers and 67 mentors have been involved in the questionnaire research. In Slovakia it has been 132 novices and 127 mentors. The semi-structured interviews have recorded the opinions of 30 novices and 8 mentors in the Czech Republic and in Slovakia 17 novices and 26 mentors. The research was supported by the Slovak National Research Agency VEGA under the project number 1/0677/12 (in the years 2012 - 2014), but Czech and Slovak cooperation continues within a new mobility project Personal and Professional Needs of Novice Teachers which is supported by the research agency APVV.
\end{abstract}

Keywords: novice teacher, mentor, professional induction

Cite This Article: Miluse Viteckova, and Zdenka Gadusova, "Teachers Professional Induction in the Czech Republic and Slovakia.” American Journal of Educational Research, vol. 2, no. 12 (2014): 1131-1137. doi: 10.12691/education-2-12-1.

\section{Introduction}

Any professional induction is quite demanding and stressful for the inductee. It usually relates to, on the one hand, previous experience and knowledge, but on the other hand, it is, at the same time, closely connected with the duties and commitments the job requires. Due to the fact that a teacher is an inseparable part of the process of education, his or her professional induction is even more demanding and requires a great deal of responsibility, as the job brings many unexpected situations and he or she is expected to solve them immediately. Newly qualified teachers usually have very good subject knowledge. Though, as Spilková [1] states "the key task for teacher training faculties is to overcome transmissive understanding of instruction.” The fact is that we can still find higher education teachers who base their teaching instruction on providing students with definitions and theories without relating them to concrete contexts of school education and personal experiences of students. This is the reason why students are not able to use their knowledge to understand more deeply and to find solutions to situations they have to face as soon as they start their teaching carrier. Application of theoretical knowledge in practice is, however, closely connected with teaching ability, which, as Průcha [2] states, is not only something that a person can learn during their studies but also includes certain attributes relating to how the person is personally equipped for performing in the teaching profession. The fact that experience is not enough to transform a teacher trainee into a real teacher is mentioned also by Švec [3]. The next factor which influences formation of personal skills and abilities is, according to Gavora [4], observation of teaching practice of other teachers, i.e. here it is mediated/second-hand experience. The importance of personal experience is mentioned also by other researchers, e.g. Rushton [5]. The problem is that many students understand, as stated by Švec [6] or Eraut [7], theory and practice as two opposite, distant poles. They expect that their higher education will provide them with recommendations and advice on how to teach and educate learners. The first year in school is therefore confrontational when comparison of ideals and reality, and at the same time theory and practice, starts and continues. Graduates of the teaching profession, with their special perception of teachers and teaching, are becoming teachers and as Urbánek [8] states, they are becoming subjects "from the opposite field."

It would be of great benefit for novice teachers, as expressed in the ETUCE report Teacher Education in Europe [9], if at least a one-year induction phase for novices were introduced, as their right and duty, in the 
form of systematic support under the auspices of experienced mentors. As stated by Průcha [10], in the majority of EU countries more or less systematic measures have been introduced with the aim of supporting novice teachers. He mentions two basic forms of support which can substitute each other: 1) supporting measures for the provision of information, advice and help, and 2) compulsory education (special courses and workshops) during novices' induction year in school. In any case, there is no unity or consistency in this field, and so the support of novice teachers in different countries of the EU varies, whether in its forms or manner of organization. The support can be compulsory or voluntary, national, regional or local. The objects of induction can be qualified teachers, fresh graduates of teacher training institutions, but also graduates without diplomas, for whom the induction phase is part of their studies and is finalized by assessment and a decision on whether they will be allowed to do the job in future. Though from the above-mentioned it is evident how unsystematic the measures to support the professional induction of teachers are, and the fact that not many countries ensure a systematic program of induction for novice teachers is also clear, some formal help and support is still provided, e.g. help with lesson planning and evaluation of lessons, regular meetings with mentors in order to discuss progress and problems, the possibility to participate in a lesson and perform observations, participation in compulsory or optional various educational activities (courses, workshops, and so on).

The Czech Republic and Slovakia used to form one country until the year 1993 and the adaptation of novice teachers was tackled systematically in Decree No. 79/1977 Coll. and No. 80/ 1977 Coll. on the uniform system of teacher training for schools providing primary, lower secondary and higher secondary education and other educational and training staff [11]. Induction of novice teachers was dealt with specifically in $\S 3$, where it was specified that mentors are appointed to all newly qualified teachers; also specified was who appoints them, what comes under their job description, and by whom and how the beginning of a teacher's professional career is monitored and evaluated. A systematic approach is also reflected in the methodology booklet issued in 1980 by the State Pedagogical Publishing House Induction of newly qualified primary and secondary school teachers [12]. The above-mentioned Decrees have been retreated from and currently the induction of novice teachers in the Czech Republic is fully the responsibility of head teachers and has no legislative basis. This, of course, has an impact on teachers' professional induction and can result in the unsystematic or random adaptation of a novice teacher with a number of errors, mistakes, and blunders. Support for novice teachers can be found in special literature, on the website www.rvp.cz (Advice for Novice Teachers) and in other publications and study materials; one cannot, however, talk about a systematic approach in this field. Nonetheless, this issue is of much interest and is widely discussed, e.g. within the design of a quality standard for the teaching profession and currently also within the national project Carrier System.

In Slovakia, teachers' professional induction is managed more systematically. Legislatively, this issue has already been dealt with in Decree No. 42/1996 on the further education of teaching staff in $\S 4$ [13]. At present,
Act No. 317/2009 on teaching staff and professional employees is applied here, and the novice teacher is addressed in $\S 28$ [14]. As to the novice teacher's professional induction, the leading role of the state is obvious; the position of a mentor-teacher has been officially introduced. In Slovak Act No. 317/2009 (see above) the function of the mentor is briefly defined together with the manner of his or her appointment and definition of job position of a mentor-teacher or professional employee as somebody who "performs specialized activities together with the performance of educational activities. .." and who is responsible for the implementation of novice teachers' induction and its continuous monitoring. The position of mentor-teacher can then be performed by an independent educator (teacher) or professional employee with the first attestation. The act partially defines specific activities and responsibilities of mentors, but it says nothing about the necessary preparation or training for this position. The first attestation and several years of teaching experience are considered to be adequate preparation for this position (the method and conditions in which to carry out attestations was set in Decree No.445/2009 on the continuous education, credits, and attestation of teaching and technical staff [15], issued by the Ministry of Education of the Slovak Republic).

Besides the official legislative standing, there is also a network of Methodology and Educational Centers (socalled MPC: Metodicko-pedagogické centrum) in all regional cities in Slovakia. These centers play quite an important role in raising teachers' awareness in many areas of education, including mentoring [16]. They organize various in-service courses and CPD activities for teachers and also publish supporting materials for novice teachers. Currently they provide supplementary methodology publications for teachers in schools and also display some recent useful information on their websites.

The term novice teacher for the purposes of this paper is used in a similar way as in the subject literature to describe a teacher in the first year of teaching at school (max. referred limit is five years). As Průcha, Walterová and Mareš [17] state, the term novice teacher can then be used to indicate a young and inexperienced teacher who "has a relevant university degree and teaching qualification, but lacks teaching experience, is at the beginning of his or her professional career (...): from the first days at school he or she performs his or her duties in full, but needs systematic advice and help and is also given tasks which he or she was not trained for...”.

The research in the area of the work of lower secondary school teachers and the problems they have to face at the start of their professional career was earlier carried out by e.g. Šimoník [18] in the Czech Republic. The following broad research in this field was carried out by Prokešová [19] and her research team. The research of her team was based on the idea that many problems the graduates of teacher training programs have to face when starting their teaching career at lower secondary schools is, besides others, caused by confrontation of three relatively independent but in the long term developed ideas. These are the ideas of higher education institutions about teaching at schools, the ideas and expectations of a particular lower secondary school and the individual expectations of a novice teacher and their ideas about 
successful teaching performance. Based on the research results, a lack of subject knowledge or basic teaching skills is the least frequent source of a subjective feeling of failure. Novice teachers instead experience intense demands in the area of their educational and social competences. They feel "unprepared for reality" and for "such an intensive and permanent contact with children", for "contempt of parents towards opinions and advice of the teacher". This research also suggests that a large emphasis is placed on empathic interactions between colleagues and the feeling of acceptance by the community of teaching staff at school. Although these results are from the year 2000, $71 \%$ of the teachers with two years of teaching at schools and $77.5 \%$ of teacher training programs' fresh graduates, who were involved in this research, would welcome an induction year.

In Slovakia, research connected with the target group of primary and lower secondary school teachers and their problems during their first year(s) in schools was carried out by Černotová [20] and Majerová [21]. Their findings about the difficult entry into teaching at primary and lower secondary schools for the majority of graduates from teacher training programs are similar to those from the research of Prokešová [19] and are closely connected with the individual preconceptions of educators, their trainees and employers.

The answers of the respondents showed that the least frequent source of subjectively perceived failure is alack of expertiseormis management of basic teaching skills. In addition, novice teachers, according to this survey, prefer interactions with colleagues that display patience and understanding, and they also seek a sense of acceptance by colleague-teachers.

Certainly, many experts, who articulate their position towards specifics related to modification of a socioprofessional teaching career while performing the job (among others Kolláriková [22]; Kasáčová [23]), as well as those who analyze and classify professional competences of teachers and who describe acquisition and development of teaching skills (among others Spilková [24]; Vašutová [25]; Belz\&Siegrist [26]; Švec\&Trna [27]; Švec et al. [28]; Blaško [29]), fully agree that up to now evaluation of teachers' needs has not been investigated enough and it is even less reflected in the design of content and in the process of continuous professional development of teachers.

The results presented in this paper are findings of the research aimed among others at novices' needs, namely in the context of their previous higher education training and support by mentors.

The aim of this paper is to answer such questions as: How is teachers' professional induction in the Czech Republic and in Slovakia managed? What are the problem areas for novice teachers? What are they lacking within their higher education training? This is all mutually linked with the importance of the mentor-teacher's role.

\section{Materials and Methods}

The paper presents the partial results of Czech and Slovak research. At first, the research was launched in Slovakia, namely in spring 2012 by the research team based at the Faculty of Arts, Constantine the Philosopher
University in Nitra (Slovakia). It was subsidized by the National Research Agency VEGA under the project number 1/0677/12 and the title Key Competences of Mentors Necessary for Successful Mentoring of Novice Teachers. The aim of this research was to identify the key competencies that are specific to the work of mentorteachers and to develop tools for shaping mentors' competencies through specially developed teaching materials.

With the aim of comparing the situation in another country, which up to the year 1993 was part of a common state and had identical schools' policy, cooperation with the Faculty of Education, University of South Bohemia in the Czech Budejovice was established in autumn 2012. In both countries mixed research has been carried out. The research sample is formed from both novice and mentor teachers. The research is based on the fact that key competences of mentors are closely related to novices' needs. Up to now in the questionnaire research, 148 novice teachers and 67 mentors have been involved in the Czech Republic and in Slovakia it has been 132 novices and 127 mentors. They were teachers from all kinds of schools (primary, lower secondary, and upper secondary) based in a variety of regions in both countries. The semistructured interviews have been recorded with 30 novices and 8 mentors in the Czech Republic and in Slovakia with 17 novices and 26 mentors.

In the context of this paper we only used the data collected from the questionnaire for novice teachers, i.e. those who do not teach in schools longer than three years (this selection was based on the definition of a novice teacher). The questionnaire included both open and closed questions. The responses were registered in a matrix and further evaluated by means of the SPSS program use. Given the focus of this paper we worked just with absolute and relative frequencies from the collected data.

In Slovakia and equally in the Czech Republic the majority of respondents in all groups have been women (83\%) and the different types of schools are proportionally represented. In the majority of cases novice teachers had chosen the teaching profession intentionally (50\% marked the answer "definitely yes" and 38\% - the answer "rather yes") and furthermore, the majority of respondents want to stay in the school system (92\%) in both countries.

\section{Results}

\subsection{Problem Areas for Novice Teachers}

What novice teachers consider to be a problem at the start of their professional career is closely related to their higher education institution training. This was one of the reasons why a question aimed at this area is included in the questionnaire. Although the collected research data are slightly different in both countries, it is possible to state that novices in both countries feel quite confident and well trained in their subject knowledge. Similar results have also been collected regarding the methodology of teaching their subjects, and work with ICT and course books. Acquisition of practical experience (including teaching practice) during their studies was slightly more positively assessed in Slovakia than in the Czech Republic. The worst evaluation was given to work with integrated pupils 
with special educational needs, followed by work with educational documents and the area of solving stressful and difficult situations (e.g. discipline of pupils). In his book Začínajícíučitel (Novice Teacher) Šimoník [30] lists 24 selected assessed activities and his research data shows that novice teachers perceive best their preparation in the area of theoretical knowledge. The least ready his respondents felt able to deal with were such activities as solving disciplinary problems, work with poorly progressing learners, work with educational documents and so on. The fact that graduates from teacher training institutions are best prepared in the subjects they teach and less prepared as to their pedagogical, psychological, and didactic skills, is stressed also in the research of Kalhous and Horák [31].

The ideas stated in the previous paragraph, assessing higher education training, are then, naturally, reflected in the perception of stressful situations during graduates' first year in schools, in the management activities for the enhancement of teacher training graduates' professional induction in the Czech Republic and in Slovakia. Students often criticize their higher education training for a lack of teaching practice; their complaints are focused, as
Wernerová [32] states, on too much theory teaching without any beneficial interconnection with school practice. Nonetheless, as Podlahová [33] states, the task of novice teachers is to integrate and use all what they have learnt and what they know in situations that are new to them, and which they do not know or just recall from memory or from teaching practice. During university studies it is not possible to provide students with comprehensive training on how to behave in all kinds of situations which may occur in real school life. For novice teachers it is important to be able to modify the knowledge learned and experiences of their studies to real situations which occur.

What novices have learned during their higher education training and, on the contrary, what they perceive as unsatisfactory, are the issues which are reflected in stressful situations during their first years in school. One of the questionnaire questions for the novices is focused on problem areas they face and need some help or advice on. In Table 1 and Table 2 the research results from both states are displayed (due to the fact that some questions have not been answered by all the respondents the final sum is not always $100 \%$ ).

Table 1. Problem areas for novices in the Czech Republic (in \%)

\begin{tabular}{|c|c|c|c|c|}
\hline I need advice or help with: & 1 & 2 & 3 & 4 \\
\hline a) selection and planning of teaching material & 2,0 & 15,5 & 64,2 & 18,2 \\
\hline b) setting and formulation of teaching aims and goals & 1,4 & 14,9 & 64,9 & 18,9 \\
\hline c) selection of the appropriate teaching strategies, teaching methods and techniques & 2,7 & 21,6 & 60,1 & 14,9 \\
\hline d) teaching what I have planned for the lesson & 1,4 & 10,1 & 59,5 & 29,1 \\
\hline e) motivation of learners to perform activities & 3,4 & 25,7 & 49,3 & 20,9 \\
\hline f) teaching process management (rules, respect, discipline, ....) & 4,1 & 24,3 & 50,7 & 20,3 \\
\hline g) interaction with learners & 2,0 & 8,1 & 65,5 & 23,6 \\
\hline h) creation of relationship with school management & 1,4 & 5,4 & 39,9 & 53,4 \\
\hline i) solving misunderstandings with colleagues & 0,7 & 4,1 & 41,2 & 53,4 \\
\hline j) solving misunderstandings with mentor & 0,7 & 0,7 & 23,0 & 73,0 \\
\hline k) learners’ parents communication & 1,4 & 20,3 & 62,8 & 14,9 \\
\hline 1) learners' evaluation and assessment & 0,7 & 19,6 & 62,8 & 16,9 \\
\hline m) work with ICT & 0,7 & 11,5 & 52,0 & 35,8 \\
\hline n) work with pedagogical documentation & 8,1 & 33,1 & 51,4 & 7,4 \\
\hline
\end{tabular}

(always -1 , usually -2 , rarely -3 , never -4 )

Table 2. Problem areas for novices in Slovakia (in \%)

\begin{tabular}{|c|c|c|c|c|}
\hline I need advice or help with: & 1 & 2 & 3 & 4 \\
\hline a) selection and planning of teaching material & 0,0 & 18,9 & 53,0 & 23,5 \\
\hline b) setting and formulation of teaching aims and goals & 0,8 & 20,5 & 53,0 & 19,7 \\
\hline c) selection of the appropriate teaching strategies, teaching methods and techniques & 0,0 & 30,3 & 43,9 & 17,4 \\
\hline d) teaching what I have planned for the lesson & 2,3 & 10,6 & 53,0 & 27,3 \\
\hline e) motivation of learners to perform activities & 4,6 & 18,2 & 41,0 & 28,8 \\
\hline f) teaching process management (rules, respect, discipline, ...) & 3,8 & 21,2 & 47,0 & 22,0 \\
\hline g) interaction with learners & 0,0 & 9,1 & 50,0 & 29,5 \\
\hline h) creation of relationship with school management & 2,3 & 8,3 & 36,4 & 45,5 \\
\hline i) solving misunderstandings with colleagues & 0,8 & 5,3 & 33,3 & 53,0 \\
\hline j) solving misunderstandings with mentor & 0,8 & 3,0 & 22,7 & 66,7 \\
\hline k) learners’ parents communication & 2,3 & 12,1 & 50,0 & 29,6 \\
\hline l) learners' evaluation and assessment & 2,3 & 18,2 & 53,0 & 18,2 \\
\hline m) work with ICT & 3,8 & 8,3 & 44,7 & 34,9 \\
\hline n) work with pedagogical documentation & 7,6 & 35,6 & 27,9 & 9,9 \\
\hline
\end{tabular}

(always -1 , usually -2 , rarely -3 , never -4 )

During the first year of their teaching in schools novice teachers both in the Czech Republic and in Slovakia seem to have been quite successful in dealing with misunderstandings with their mentors and colleagues, and with establishing a good relationship with school management. As the research results show, establishing and maintaining good interpersonal relationships has been the least problematic area novices have faced. If we added the number stated for the answer "always", "usually", "rarely", and " never", then it is interesting to see that
Czech teachers in comparison with Slovak ones prefer counseling in the area of learners' motivation to perform presented or planned activities, as opposed to help with selection of the appropriate learning strategies, teaching methods and techniques. Though in reality, motivation of learners is highly influenced especially by selection of the appropriate learning strategies, teaching methods and techniques. Another interesting fact is that novices perceive work with pedagogical documentation as the most problematic area. This finding has also been 
confirmed in the following interviews with novices. The interviewed respondents stated in them: "Despite the very friendly and generous environment which was created by my new colleagues, I constantly had a feeling that I still did not know something ... that I was not fully aware of the relevant school legislation and some important documents...". The question is whether one of the aims of higher education training should be teaching and learning how to manage administrative tasks of teachers. These findings may, at the same time, point to the fact how much attention is paid to paper work in schools, what importance is placed on it and to what extent it is perceived as a stressful burden. The findings and especially the findings in the area of paper work of teachers reflect undoubtedly the fact Průcha [10] pointed to earlier that while in other professions demands and requirements usually increase step by step, teachers experience their "professional shock" immediately after they start their work in schools, and especially during their first year in the teaching job. They are required to deal with a variety of tasks and obligations from the very first day in school, including the position of a class teacher, which is especially a very demanding job, as it is connected with large amounts of administrative work.

\subsection{Novices’ Needs}

Out of the options provided in the questionnaire to choose from, novices have declared none as very urgent to be "improved". All the offered needs have been evaluated very similarly and it has been stated that they are required "to some extent". If we ordered them in terms of frequency, then we could see that novices experience the greatest need (which means also the greatest discomfort) in the area of learning how to coordinate and manage administrative duties, where to find information about pedagogical documentation and how to learn required skills in dealing with those documents. The following area, which is to some extent considered as a valuable one to develop more, is special methodology support and counseling and development of teaching skills. A large emphasis is placed on emotional support from relatives, friends and colleagues, too. This finding corresponds with the above-mentioned research findings of Prokešová [19]. As not needed or least needed were the improvement of communication and interpersonal skills. In open questions the need for more teaching practice again occurs: "I need more practice so I can learn from the examples of good and bad practice how teaching performance in lessons should as well as should not look like".

\subsection{Mentor Support of Novices}

In the Czech Republic and in Slovakia teachers' professional induction differs in the manner of the official appointment of a mentor. As opposed to Slovakia, in the Czech Republic the appointment of mentors is in the hands of head teachers. The questionnaire findings show that in the Czech Republic only $71.6 \%$ of novice teachers had mentors and out of that number only $61.5 \%$ of them were appointed by head teachers. In all the other cases mentors were either warm-hearted colleagues willing to help and counsel, or in some cases mentors were family members who worked in schools. When novices assess their relationship with their mentors they choose the answer "excellent" in 46.7\% (in CR) and 45.5\% (SK), "very good" in 34.6\% (in CR) and 29.6\% (SK), and "good" in $17.8 \%$ (in CR) and $22.7 \%$ (SK). These very positive experiences of novices with mentors document that in both countries support of novices by mentors is predominantly at the level of professional and personal counseling. The fact that novices experience serious problems with pedagogical documentation is in direct relation with their answers to the question whether mentors meet them and discuss their problems with them "regularly and systematically". A large difference connected with their official appointment in Slovakia can be seen in the answers to the question "How often did you have contacts with your mentor?” In the Czech Republic the most frequent have been the answers "over longer time periods, at random", "rarely, upon request" (total $52.3 \%$ ), whereas in Slovakia in 58.3\% the stated answer has been "regularly and systematically". Similarly Slovak mentors (50\%) have observed their novices "regularly and systematically" and only $20.5 \%$ of mentors have done that "over longer time periods, at random". In the Czech Republic it has been vice versa, in $50.5 \%$ of cases it has been answers "over longer time periods, at random” and only $15.8 \%$ of mentors stated that they have done it "regularly and systematically".

Novice teachers in both countries expect first of all that their mentors will be experienced professionals with a professional approach to them, and that they will behave in a friendly and helpful manner. Professional expertise and mastery as well as highly developed professional experience of mentors take second place in novices' expectations. Another important phenomenon that novices highly appreciate is willingness of mentors to solve problems or give advice on how to solve them and allocation of time for discussions. On the other hand, novices do not expect their mentors to give them additional, supplementary teaching materials as inspiration for lesson planning and positive assessment of their use of new innovative teaching methods or techniques.

The questionnaire findings from mentors also show that mentors place the largest emphasis on provision of personal and professional support for novice teachers; then follow such aspects as provision of guidance and information when planning lessons, use of teaching aids, help with the assessment of pupils follow. At the same time, stating the above-mentioned aspects of mentors' counseling as important for novices, mentors feel themselves very confident in providing this kind of help and advice. On the contrary, the least confident they feel themselves when it comes to their role as a critical friend, is if they have to provide constructive feedback for a novice. Mentors feel equally less confident in both countries if they are asked to observe and monitor a novice's progress and assess it.

The difference in induction management between the Czech Republic and Slovakia, as mentioned above, is in legislation. In the questionnaire item for mentors where it is stated: "officially appointed" in the Czech Republic the answer "yes" has been stated in $49,3 \%$ of cases and "no" in $50.7 \%$ of cases. In Slovakia $75 \%$ of mentors have answered "yes" and only 25\% of the respondents have stated "no". One of the positive findings in the questionnaire for mentors is also their answer to the question "Did you want to become a mentor?" The answer 
by the majority of mentors has been "yes" (in the Czech Republic it has been $58.2 \%$ and in Slovakia $72.4 \%$ ). Another interesting, but not surprising, finding is that despite the fact that in Slovakia all mentors should be officially appointed (as there is legislation which requires it) and as the data stated above show in the majority of cases appointment of a mentor is an official event, the findings from the answers to the following questionnaire question "Have you been told what the duties of a mentor are?" show that almost no one cares about mentors' awareness of their duties. Though at first glance it may seem that in Slovakia mentors are more aware of their duties $(82.5 \%$ of mentors answered the question with a "yes" in comparison with $65.7 \%$ of those in the Czech Republic) but as stated in their open question asking "Who did it and how?", their answers have been very laconic and vague, replying with statements such as "school managers", "colleagues”, "self-study of special literature”, and no answer to "How?" As to the further education (CPD) of the appointed mentors in the field of mentoring in both countries almost no one has attended any course or workshop on this topic (the findings from all of the questionnaires is that in the Czech Republic only one mentor and in Slovakia two mentors - if that is at all true, attended some education course in this field).

The questionnaire research for novice teachers confirmed that the role of mentors is irreplaceable. Though novice teachers perceive their theoretical training in higher education institutions as satisfactory, they still consider the help of their more experienced colleagues in new work places to be of vital importance. The start of the professional teaching career, irrespective of the knowledge acquired during their studies, is very demanding. The education process in schools brings about many unexpected situations, and it is also influenced not only by the personalities of children but also by administrative requirements, a gender-unbalanced school staff, the demands of school managers and at the same time by ideas and requirements of learners' parents.

\section{Discussion}

How, then, is a teacher's professional induction organized in the Czech Republic and in Slovakia, in countries with a common history? What areas of their university training do novice teachers perceive as problematic? What do they lack in their higher education training? The difference is, first of all, in the systematic view of the mentor's role. In Slovakia the function of a mentor teacher is determined by legislation which also defines the manner of his or her appointment and the mentor's job position. In the Czech Republic the appointment of a mentor-teacher is fully the competence of head teachers. Currently, however, they are implementing the project Kariernísystém (Career System) in the Czech Republic and one of its results should be a more systematic treatment of the role of mentor-teacher.

The findings from the questionnaire research have shown that novice teachers experience the greatest drawbacks in the area of their administrative performance; they feel a lack of knowledge about pedagogical documentation. However, personal and professional support from colleagues or from the closest colleague who should be their mentor is considered to be the most important. Novices feel very confident as far as their theoretical knowledge training goes but the question is whether they are able to implement and modify all this knowledge in situations which unexpectedly arise while teaching at schools. In the context of higher education training of teachers one can often encounter the opinion that there is not enough time and space allocated for teaching practice of future teachers, that they do not have enough opportunities to deal with difficult situations and difficult learners, that they have no opportunities to become aware of how to deal with learners with special needs. Generally speaking, higher education institutions training future teachers still place more emphasis on theoretical preparation of their graduates as they consider it more appropriate for the academic environment and very often these academics are scared to admit that their trainees need to be exposed also to the environment where they will work. On the other hand, one should also consider what Švec [3] says and that is that experience on its own is not enough for a trainee teacher to become a real teacher and that the personal traits of the individual, their empathy and other personality phenomena play an important role in this process.

\section{Conclusion}

Bearing in mind the current demands on the increase of quality of teachers and changes in the educational context, it is legitimate to introduce relevant changes into the transmissive understanding of education in higher education institutions, in the training of future teachers, and increase the number of teaching practice lessons at teacher training institutions, but also introduce and maintain systematic support of novice teachers after their graduation. In our opinion, higher education training of future teachers is inseparable from their first year in schools after graduation. The ideal solution would be a legislatively anchored one-year induction phase for novice teachers under the auspices of mentors. However, the appointed mentors should also be trained for their role school managers shouldn't rely only on the experience of mentors. For this purpose the research team of the VEGA project has developed a set of practical training materials to develop relevant competences of mentors. The materials have been piloted at workshops with a number of in-service teachers and have received very positive feedback. After publication they will serve as aids for the CPD of teachers. In the Czech and Slovak context they will be the first publication of this type and will serve similar purposes as the publication The Flemish Teacher Education Development Profile [34].

\section{Acknowledgement}

The paper has been written as a result of the Czech and Slovak research findings within the research project VEGA 1/0677/12 Key Competences of Mentors Necessary for Successful Mentoring of Novice Teachers and on the basis of cooperation in the stated field of research between the Faculty of Arts, Constantine the Philosopher University in Nitra (Slovakia) and Faculty of Education, 
University of South Bohemia in České Budějovice (Czech Republic).

\section{References}

[1] Spilková, V., "Proměnyvzděláváníučitelů $\quad$ v kontextukurikulárníreformy, in Kratochvílová, J. a Horká, H. (ed.) Proměnyučitelskéhovzděláváni kontextureformyzákladníhoškolství: $\quad$ sborník $\quad$ Z pracovníhoseminářekonanéhodne 15. 3. 2007 na Pedagogickéfakultě MU. Masarykovauniverzita, Brno, 9-17.

[2] Průcha, J., Učitel: Současnépoznatky o profesi, Portál, Praha, 2002.

[3] Švec, "Ohlédnutízadesetiletýmvývojempedagogicképř́pravybudoucíchu", čitelů“, Pedagogickáorientace, 4. 31-43. 2005.

[4] Gavora, P., "Učitel'ovovnímaniesvojejprofesijnejzdatnosti (selfefficacy)”, Pedagogika, LVIII (3). 222-235. 2008.

[5] Rushton, S., "Student Teacher Efficacy in Inner-City Schools“, The Urban Review, 32 (4), 365-383. 2000.

[6] Švec, V., "Pedagogikameziteorií a praxí“. In Prokop, J. a Rybičková, M. (ed.) Proměnypedagogiky. Sbornikpř́spěvků z 13. Konference $\check{C} P d S$, UK PedF, Praha, 2005, 75-85.

[7] Eraut, M., Developing Professional Knowledge and Competence, TheFalmer Press, London, 1994.

[8] Urbánek, P., Vybranéproblémyučitelsképrofesel Aktuálníanalýza, Technickáuniverzita v Liberci, Liberec, 2005.

[9] ETUCE. Teacher Education in Europe. An ETUCE Policy Paper. 2008.

[10] Průcha, J. (ed.)., Pedagogickáencyklopedie, Portál, Praha, 2009.

[11] Vyhláška č. 79/1997 $\quad$ Sb. a č. 80/1997, o jednotnémsystémudalšíhovzděláváníučitelůškolposkytujícíchzákla dní, střední a vyššívzděláníaostatníchpedagogických a výchovnýchpracovníků.

[12] Tmej K., Uváděnízačinajícíchučitelůzákladních a středníchškol do praxe, SPN, Praha, 1980.

$\begin{array}{llllll}\text { [13] Vyhláška } & \text { č. } & 42 / 1996 & \text { Z. } & \text { z. } & \text { o }\end{array}$ d’alšomvzdelávanípedagogickýchpracovníkov.

[14] Zákon č.
pedagogickýchzamestnancochaodbornýchzamestnancoch.

[15] Vyhláška č. $445 / 2009$ Z. $\quad$ z. $\quad$ o kontinuálnomvzdelávaní, kreditochaatestáciáchpedagogickýchzamestnancov a odbornýchzamestnancov.
[16] Výbohová

D.,

D., Príprava

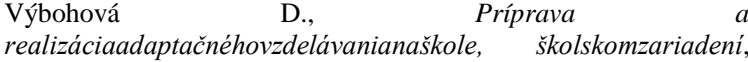
MPC, Bratislava, 2012.

[17] Průcha J., Walterová E., Mareš J., Pedagogickýslovník, Portál, Praha, 2001.

[18] Šimoník, O., Začínajíciučitel, Masarykovauniverzita, Brno, 1994.

[19] Prokešová L., Učitelzákladníškoly a jehoproblémypřinástupu do praxe, in Učitel a jehouniverzitnívzdělávánínaprelomutisíciletí, UniverzitaKarlova, Praha, 2000, 205-209.

[20] Černotová, M. et al., Cvičníučitelia, FHPV PU, Prešov, 2010.

[21] Majerová, T., Potrebujúsazačínajúciučiteliakontinuálnevzdelávat?, 2011. [Online] Available: http://www.pulib.sk/elpub2/FHPV/Istvan1/pdf_doc/3sekcia/Majer ova.pdf

[22] Kolláriková, Z., "Fázyutváraniaučitel'skejprofesie“. Pedagogická revue, 45 (9-10). 483-493. 1993.

[23] Kasáčová, B., Učitel - profesia a príprava, PF UMB, Banská Bystrica, 2002.

[24] Spilková, V., "Východiskavzděláváníučitelůprimárníchškol". Pedagogika, 46 (2), 46-52. 1996.

[25] Vašutová, J., Kvalifikačnípředpoklady pro nové role učitelů, in Walterová, E. (ed.) Učiteléjakoprofesniskupina, jejichvzdélávání a podpůrnýsystém. 1. díl. 19-46. PedF UK, Praha, 2001.

[26] Belz, H., Siegrist, M., Kličovékompetence a jejichrozvijení, Portál, Praha, 2001.

[27] Švec, V., Trna, J., Osvojováníklíčovýchkompetencíučitele, in ZborníkMedacta 99. Učitel’ pre tretietisicročie. Slovdidac, Nitra, 1999, 168-171.

[28] Švec, V. a kol.,Cesty $k$ učitelsképrofesi: utvářeni a rozvíjenípedagogickýchdovedností, Paido, Brno, 2002.

[29] Blaško, M., Úvod do modernejdidaktiky I. (Systémtvorivohumanistickejvýučby), Katedrainžinierskejpedagogiky Technickejuniverzity, Košice, 2010.

[30] Šimoník, O., Začinajícíučitel, Masarykovauniverzita, Brno, 1994.

[31] Kalhous, Z., Horák, "K aktuálnímproblémůmzačínajícíchučitelů“. Pedagogika. XLVI (3). 245-255. 1996.

[32] Wernerová, J., "Hodnoceníprofesnípřípravy student učitelství a jejichpostoje k profesi“, e-PEDAGOGIKUM, 8, 24-37. 2013.

[33] Podlahová, L., Prvnikrokyučitele, Triton, Praha, 2004.

[34] Janssens, S. (ed.), The Flemish Teacher Education Development Profile, Vereninging Lerarenopleiders Vlaanderen, Antwerpen, 2012. 